\title{
Effect of Fertigation-Applied Sulfuric Acid on Phosphorus Availability and Some Microelements for Greenhouse Cucumber
}

\author{
Hemn O. Salih* \\ Plant Production Department, Khabat Technical Institute, Erbil Polytechnic University, Erbil, Iraq
}

Received: 17 August 2020

Accepted: 11 February 2021

\begin{abstract}
Aim of study: Essential nutrient elements such as $\mathrm{P}, \mathrm{Fe}, \mathrm{Zn}, \mathrm{Cu}, \mathrm{B}$ and $\mathrm{Mn}$ are mostly affected by soil $\mathrm{pH}$. In calcareous soils, it is often difficult to obtain a $\mathrm{pH}$ of 6-6.5 the optimum soil $\mathrm{pH}$ value of phosphorus and micronutrients, as the goal of fertilizer best management practices is to match nutrient supply with crop requirements to optimize yield while minimizing nutrient losses to the environment. Material and methods: In order to study the addition of different amounts of sulfuric acid through irrigation to minimize soil $\mathrm{pH}$ value, and to improve the availability of the elements on cucumbers, experiments were carried out on two types of soil textures: Silty Clay Loam (S1) and Silty Clay (S2). The sulfuric acid was applied with different concentrations $\left(0,0.5,1,3\right.$, and $\left.5 \mathrm{ml} \mathrm{L}^{-1}\right)$. The elements' concentration was studied at three soil depths $(\mathrm{D} 1=0-10, \mathrm{D} 2=10-20$ and D3 $=20-30) \mathrm{cm}$. Results: The availability of $\mathrm{P}$ and micronutrients primarily increased in $\mathrm{C} 4 \mathrm{D} 3$ in $\mathrm{S} 2$ soil. The $\mathrm{P}$ in this work was a positive correlation with $\mathrm{Zn}$ in both soils, while it showed a negative correlation with other micronutrients $(\mathrm{Fe}, \mathrm{Cu}, \mathrm{B}$ and $\mathrm{Mn})$. Element concentration in plant tissue was studied in the plant residues after harvesting. The $\mathrm{C} 3$ was highly effective in increasing the elements $(\mathrm{P}, \mathrm{Fe}, \mathrm{Zn}, \mathrm{Cu}, \mathrm{B}$, and $\mathrm{Mn}$ ) in plant tissues in both soils, and had a significant effect on the increase in cucumber yield. Conclusion: The values of soil $\mathrm{pH}$ were regularly decreased by increasing sulfuric acid. Then, the availability of the studied elements was enhanced.
\end{abstract}

Keywords: phosphorus, calcareous soil, cucumber yield, soil pH, microelements availability

\section{Introduction}

Cucumber (Cucumis sativus L.) is considered to be one of the most important vegetables and is a popular member of the Cucurbitaceae family [1]. Most nutrients are recommended to be necessary to improve cucumber

*e-mail: hemn.salih@epu.edu.iq yield and product quality [2]. However, integrated plant nutrient and soil fertility management share similar objectives namely to ensure efficient nutrient uptake and plant growth with minimal adverse impacts on the environment. Crop yield and quality will be restricted if the rate is too low while excess application can lead to crop damage and negative environmental impacts [3]. Among these nutrients, phosphorus $(\mathrm{P})$ is deemed the most important macro element to the plant, as it is vitally connected to a number of functions in the plant 
including photosynthesis, energy transfer, respiration, and cell division [4]. Also, micronutrients contribute to numerous physiological processes. For example, iron (Fe) is a component of several enzymes involved in various biological processes including respiration and photosynthesis; zinc $(\mathrm{Zn})$ is an important component of many enzymes, and a structural stabilizer of proteins and plant membranes; manganese (Mn) is an active component of the water-splitting system of photosystem II that supplies the electrons necessary for photosynthesis; copper $(\mathrm{Cu})$ is a redox transition element with an important function in photosynthesis, respiration, and the metabolism of carbon (C) and nitrogen $(\mathrm{N})$. $\mathrm{Cu}$ also induces protection against oxidative stress, and boron (B) participates in cell division, water relations, ion adsorption, the metabolism of carbohydrates, and the translocations of sugar and fruit [5]. Furthermore, the availability of these nutrients are mainly affected by soil type, in particular, calcareous soils due to a high $\mathrm{pH}$ value. Iraqi soils are categorized in this class of soil $[6,7]$.

Sheikh-Abdullah [8] confirmed that active $\mathrm{CaCO}_{3}$ negatively influences the availability of micronutrients such as Fe, Zn and Mn. Khorsandi [9] stated that better P solubility occurs at a $\mathrm{pH}$ ranging between 6-6.5. Several methods have been reported to benefit a reduction in $\mathrm{pH}$ value and then increase nutrient availability; for example, adding sulfur to the soils then oxidation into $\mathrm{H}_{2} \mathrm{SO}_{4}$ results in increasing the availability of nutrients by reducing soil $\mathrm{pH}$ [10]. However, the direct use of sulfuric acid into the soil to minimize the $\mathrm{pH}$ value might be helpful to increase soil nutrient availability [9]. In Iraqi calcareous soils, the factor of adding sulfuric acid to improve nutrient availability has not been carried out; thus, this study aimed to add sulfuric acid at different concentrations to lower soil $\mathrm{pH}$ under plastic house conditions, and illustrate its impact on the growth and yield of cucumbers, as well as the availability of $\mathrm{P}$, $\mathrm{Fe}, \mathrm{Zn}, \mathrm{Cu}, \mathrm{B}$ and $\mathrm{Mn}$.

\section{Materials and Methods}

The experiments were conducted at the Agricultural Research Station in Grdarasha (412 m, 36 07'10.44"N - 4400'50.52"E), about $4 \mathrm{~km}$ south of Erbil centre,

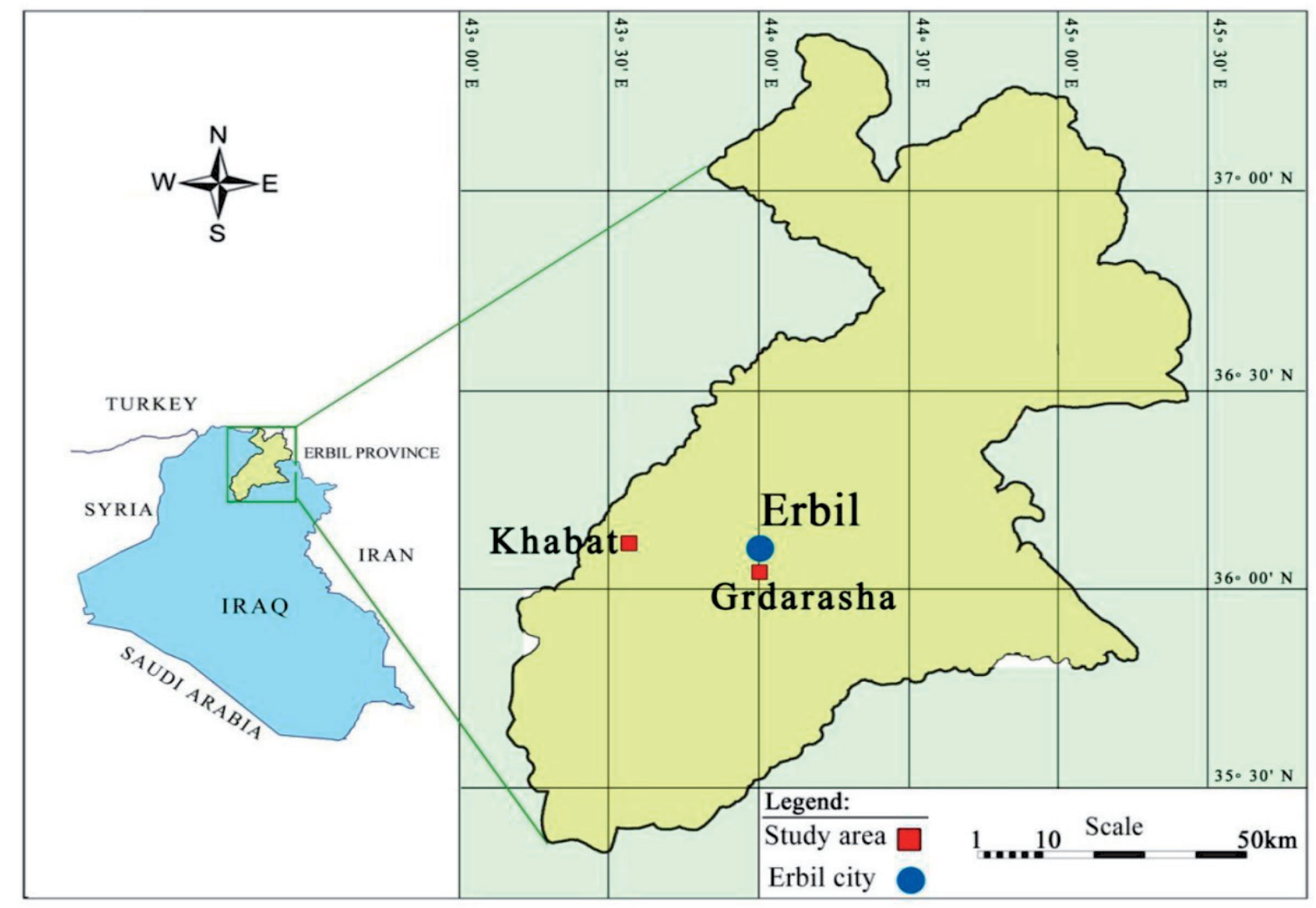

\begin{tabular}{|c|c|c|c|}
\hline Locations & Latitude & Longitude & Elevation $(\mathbf{m})$ \\
\hline Grdarasha & $36^{0} 07^{\prime} 10.44^{\prime \prime} \mathrm{N}$ & $44^{0} 00^{\prime} 50.52^{\prime \prime} \mathrm{E}$ & 412 \\
\hline Khabat & $36^{0} 15^{\prime} 53.18^{\prime \prime} \mathrm{N}$ & $43^{0} 39^{\prime} 21.28^{\prime \prime} \mathrm{E}$ & 246 \\
\hline
\end{tabular}

Fig. 1. The experiments location map. 
and at Khabat Agricultural Technical Institute (246 m, 36 $\left.36^{0} 15^{\prime} 53.18^{\prime \prime} \mathrm{N}-43^{0} 39^{\prime} 21.28^{\prime \prime} \mathrm{E}\right), 30 \mathrm{~km}$ west of Erbil centre, under plastic house conditions during the summer season of 2016 (Fig. 1). The experiments were carried out to evaluate the impact of applying different concentrations of sulfuric acid directly to soils on $\mathrm{P}$ and certain micronutrients including $\mathrm{Fe}, \mathrm{Zn}, \mathrm{Cu}, \mathrm{B}$ and $\mathrm{Mn}$, and its effect on the growth and yield of the Rainbow variety of cucumber.

At the site of the plastic houses, the land was prepared through ploughing, harrowing and levelling, and two samples from the site were taken $(0-30 \mathrm{~cm})$ to determine some of the chemical and physical properties of the soils under study (Table 1). Next, the experimental sites were shaped into mounds. Every experimental unit included a mound of $4 \mathrm{~m}$ in length, and ten plants were cultivated in every mound with a spacing of $40 \mathrm{~cm}$ between plants. Also, $75 \mathrm{~cm}$ was left between every experimental unit. Five concentrations of sulfuric acid $\left(0,0.5,1,3\right.$, and $\left.5 \mathrm{ml} \mathrm{L}^{-1}\right)$ were applied into the soil surface for two types of soils. This was determined according to the USDA soil textural classification [11], including Silty Clay Loam $(\mathrm{SiCL}=\mathrm{S} 1)$ and Silty Clay $(\mathrm{SiC}=\mathrm{S} 2)$, to the Grdarasha and Khabat soils, respectively. During the experiment, the crop was irrigated every two weeks; the total watering was eight times to avoid acid accumulation in the soil. The study took a chemical analysis of the soil at both locations ( $\mathrm{pH}, \mathrm{P}, \mathrm{Fe}, \mathrm{Zn}, \mathrm{Cu}, \mathrm{B}$ and $\mathrm{Mn}$ ). The soils were sampled by end harvesting with an auger drill at three depths (0-10, 10-20, 20-30) cm. Also, the concentration of P, Fe, $\mathrm{Zn}, \mathrm{Cu}, \mathrm{B}$ and $\mathrm{Mn}$ in the plant was analysed by sampling the above-ground plant-parts at the end of harvest, in addition to the cucumber yield. Available Fe, Mn, Zn, and $\mathrm{Cu}$ contents of the soil samples were extracted with $0.005 \mathrm{M}$ diethylenetriamine pentaacetic acid $+0.01 \mathrm{M}$ $\mathrm{CaCl}_{2}+0.1 \mathrm{M}$ triethanol amine, and the extractable elements were determined on an atomic absorption spectrophotometer as described by Lindsay and Norvell [12]. Furthermore, the plant samples were digested and prepared for total element determination by inductively coupled plasma-atomic emission spectrometry [13]. In addition, the experiments were designed according to Factorial Randomized Completely Block Design (RCBD). In all cases, Tukey's H.S.D multiple range tests were applied at $(\mathrm{P} \leq 0.05)$ for comparison between the means of treatments using SPSS 25.0.

\section{Results and Discussion}

\section{Soil Properties}

The results showed the significant effects of sulfuric acid levels at the end of the growing season for both soils at different soil depths in reducing $\mathrm{pH}$ in the soil solution. The fourth concentration of sulfuric acid and a 0-10 $\mathrm{cm}$ soil depth had a greater decrease of soil $\mathrm{pH}$ value compared to other the treatments. As a result,

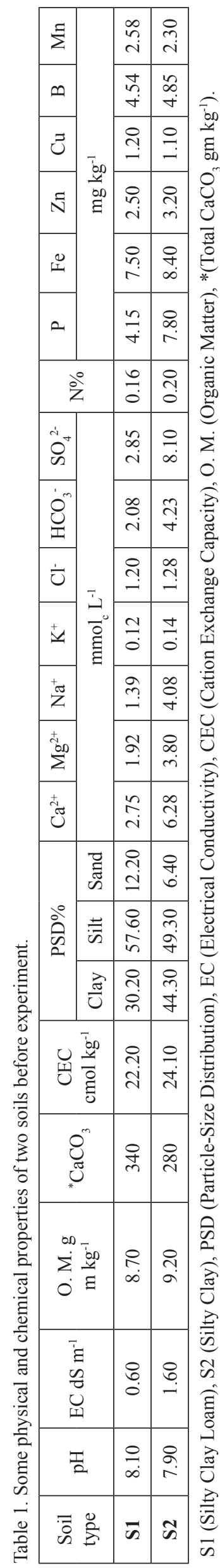



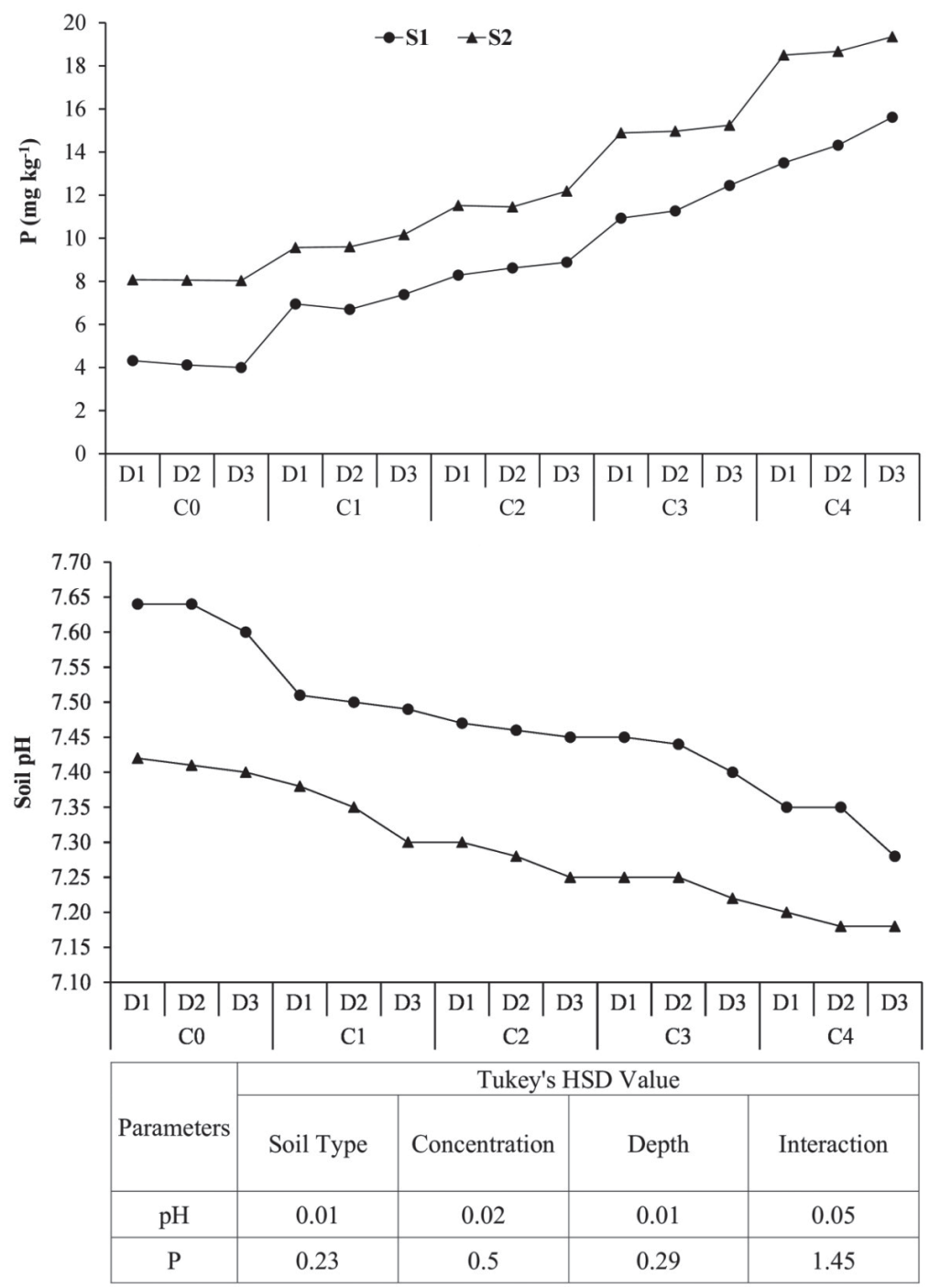

Fig. 2. Effect of sulfuric acid concentrations on $\mathrm{pH}$ and phosphorus availability in two different soils and three depths $(\mathrm{S} 1=\mathrm{Silty} \mathrm{Clay}$ Loam, $\mathrm{S} 2=$ Silty Clay, $\mathrm{C}=$ Concentration, $\mathrm{D}=$ Depth, Significant at $\mathrm{P} \leq 0.05$ ).

the availability of phosphorus was primarily increased, in particular, by a $5 \mathrm{ml}$ treatment of sulfuric acid and 20-30 cm depths for both soils (Fig. 2). Furthermore, the maximum concentration of micronutrients (Fe, $\mathrm{Zn}, \mathrm{Cu}, \mathrm{B}$ and $\mathrm{Mn}$ ) was obtained by the fourth concentration of sulfuric acid and the third depth of soil in both experiments compared to other treatments. On the other hand, better results for the concentration of micronutrients was obtained in Khabat soils due to the high content of clay particles, particularly in the fourth concentration of the sulfuric acid and the third depth of the soil (Fig. 3). The calcite amount in the soil was diminished, possibly due to the dissolution of the lime by acid. This emphasized that the application of acid to calcareous soils dramatically decreases the $\mathrm{pH}$ value of the soil as a result of neutralizing soil $\mathrm{CaCO}_{3}$. A very low soil $\mathrm{pH}$ is obtained as the sulfuric acid results in a low $\mathrm{pH}$ in the soil solution. As a result, some of the phosphate compounds are dissolved, and then the available phosphorus is released [14]. In addition,
Sumner and Yamada [15] found that soil acidification results in increasing the concentration of some nutrient elements in the soil solution, particularly phosphorus.

It is commonly known that there is a direct relationship between soil $\mathrm{pH}$ and $\mathrm{CaCO}_{3}$ in soil. When a high concentration of sulfuric acid was added to the soils, the $\mathrm{pH}$ tended to an extremely low value, and then the activity of $\mathrm{CaCO}_{3}$ was diminished. After the active carbonate calcium was restricted, most of the micronutrients are available. Sheikh-Abdullah [8] found a negative correlation between the availability of $\mathrm{Fe}, \mathrm{Zn}$ and $\mathrm{Mn}$, and $\mathrm{CaCO}_{3}$ activity. Then, the rate of micronutrients markedly increased. In soil with a low $\mathrm{pH}$, most micronutrients are at their peak availability; this is probably due to the strong attraction of $\mathrm{H}^{+}$ions to the negative site on the surface of the soil particles, which is then sufficiently replaced by other cations. Consequently, these cations are released to the soil solution obtaining better availability [16]. In addition, Ghehsareh and Samadi [17] found that acidification 

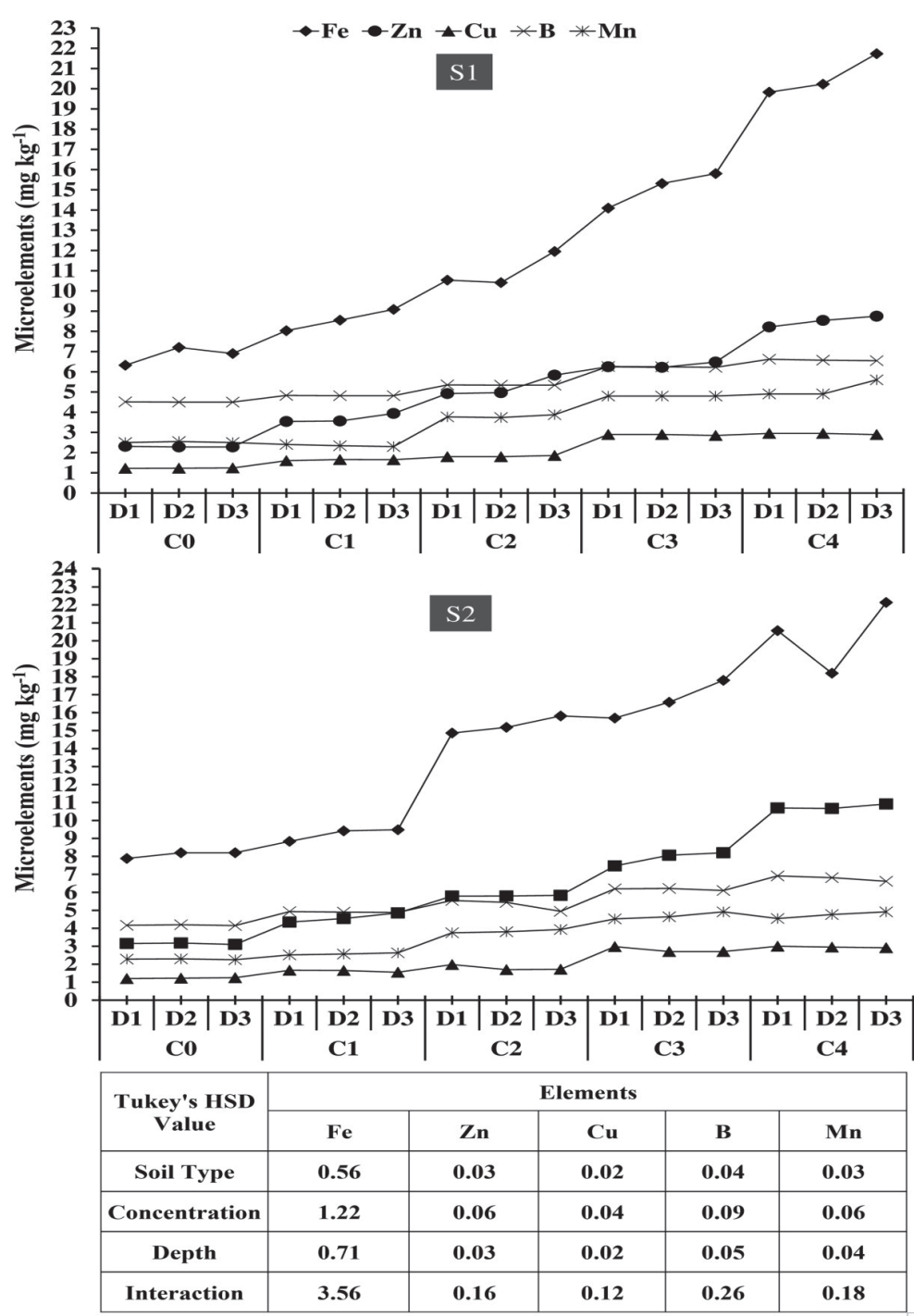

Fig. 3. Effect of different sulfuric concentrations on micronutrient availability in two soils $(\mathrm{S} 1=$ Silty Clay Loam, S2 = Silty Clay, $\mathrm{C}=$ Concentration, $\mathrm{D}=$ Depth, Significant at $\mathrm{P} \leq 0.05$ ).

of soil can result in the dissolution of soil minerals, particularly microelement minerals. In addition, the correlations between $\mathrm{P}$ and micronutrients were varied (Fig. 4). The $\mathrm{P}$ in this work was a positive correlation with $\mathrm{Zn}$ in both soils, while it showed a negative correlation with other micronutrients $(\mathrm{Fe}, \mathrm{Cu}, \mathrm{B}$ and $\mathrm{Mn})$. In contrast, the work of [18] showed different results, as $\mathrm{Zn}, \mathrm{Cu}$ and $\mathrm{B}$ decrease with an increase in $\mathrm{P}$ concentration in the soil, whereas $\mathrm{Fe}$ and $\mathrm{Mn}$ showed a positive correlation.

Besides soil $\mathrm{pH}$ as a factor that affects micronutrient availability, soil texture is also deemed an important feature that influences the nutrient elements [19]. However, finer-textured clay soils often display more concentrations of micronutrients and can endure higher $\mathrm{pH}$ compared to sandier soils [20]. Silva et. al. [21] explained that soils with a sand texture contain the lowest $\mathrm{Fe}, \mathrm{Mn}, \mathrm{Zn}$, and $\mathrm{Cu}$, and the researchers stated that the average content of micronutrients in these soils was 4-10 times lower than those of clay loam and loam texture soils at $0.00-0.20 \mathrm{~m}$ layer. In addition, Najafi-Ghiri et. al. [22] in their work on the availability of micronutrients in calcareous soil, found that a better content of clay in the soil showed preferable concentrations of micronutrients. These cations exist in the soil solution and can bind to negative charges of clay minerals by external sphere (ion exchange) or internal sphere (specific adsorption) bonds [21].

In calcareous soils at both locations, a high level of active lime can result in the release of calcium carbonate to the soil solution, which causes an increase in soil $\mathrm{pH}$. As a result, the iron element is precipitated, as iron hydroxide is formed in the soil and is unavailable to be absorbed by the plants. In addition, increasing soil $\mathrm{pH}$ can reduce available $\mathrm{Cu}$ concentration due to the precipitation of the element as $\mathrm{Cu}(\mathrm{OH})_{2}$. However, the available form of Mn mainly depends on dissolving manganese compounds in soil, which occurs under low soil $\mathrm{pH}$. Also, soil microorganisms, which influence the availability of manganese reduction, rely markedly 


\begin{tabular}{|c|c|c|c|c|c|c|c|}
\hline & 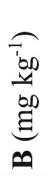 & 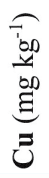 & 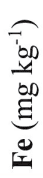 & 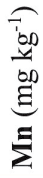 & 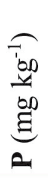 & $\begin{array}{l}\frac{\pi}{2} \\
\overline{\bar{c}} \\
\stackrel{\bar{b}}{2}\end{array}$ & 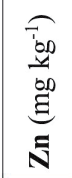 \\
\hline \multicolumn{8}{|l|}{$\mathbf{B}\left(\mathrm{mg} \mathrm{kg}^{-1}\right)$} \\
\hline \multicolumn{8}{|l|}{$\mathrm{Cu}\left(\mathrm{mg} \mathrm{kg}^{-1}\right)$} \\
\hline \multicolumn{8}{|l|}{$\mathbf{F e}\left(\mathrm{mg} \mathrm{kg}^{-1}\right)$} \\
\hline \multicolumn{8}{|l|}{$\mathbf{M n}\left(\mathrm{mg} \mathrm{kg}^{-1}\right)$} \\
\hline \multicolumn{8}{|l|}{$\mathbf{P}\left(\mathrm{mg} \mathrm{kg}^{-1}\right)$} \\
\hline \multicolumn{8}{|l|}{ Soil pH } \\
\hline $\mathbf{Z n}\left(\mathrm{mg} \mathrm{kg}^{-1}\right)$ & & & & & & & \\
\hline
\end{tabular}

Fig. 4. Heat map of Pearson correlation coefficients between available forms of micronutrients and phosphorus of the studied soil at three depths $(0-10,10-20$ and 20-30 cm). on soil $\mathrm{pH}$, and the optimum value of $\mathrm{pH}$ for soil microorganism activity is around 7. Furthermore, the sharp decrease in $\mathrm{Zn}$ concentration above $\mathrm{pH} 7$ appears to be the result of the decreased concentration of $\mathrm{Zn}^{2+}$ species and the increase in hydrolysed forms of $\mathrm{Zn}(\mathrm{OH})^{+}$and $\mathrm{Zn}(\mathrm{OH})_{2}$ [22].

\section{Soil Textures}

Micronutrient concentration was higher at soil type S2, which contains higher clay content. It was observed that soils with high clay content have greater adsorptive capacities and higher bonding energies for micronutrients [24]. In addition, Rengel [25] confirms that micronutrients ( $\mathrm{Fe}, \mathrm{Zn}, \mathrm{Cu}$ and $\mathrm{Mn}$ ) have better availability with a relatively higher proportion of clay. Furthermore, the availability of B is greater with higher
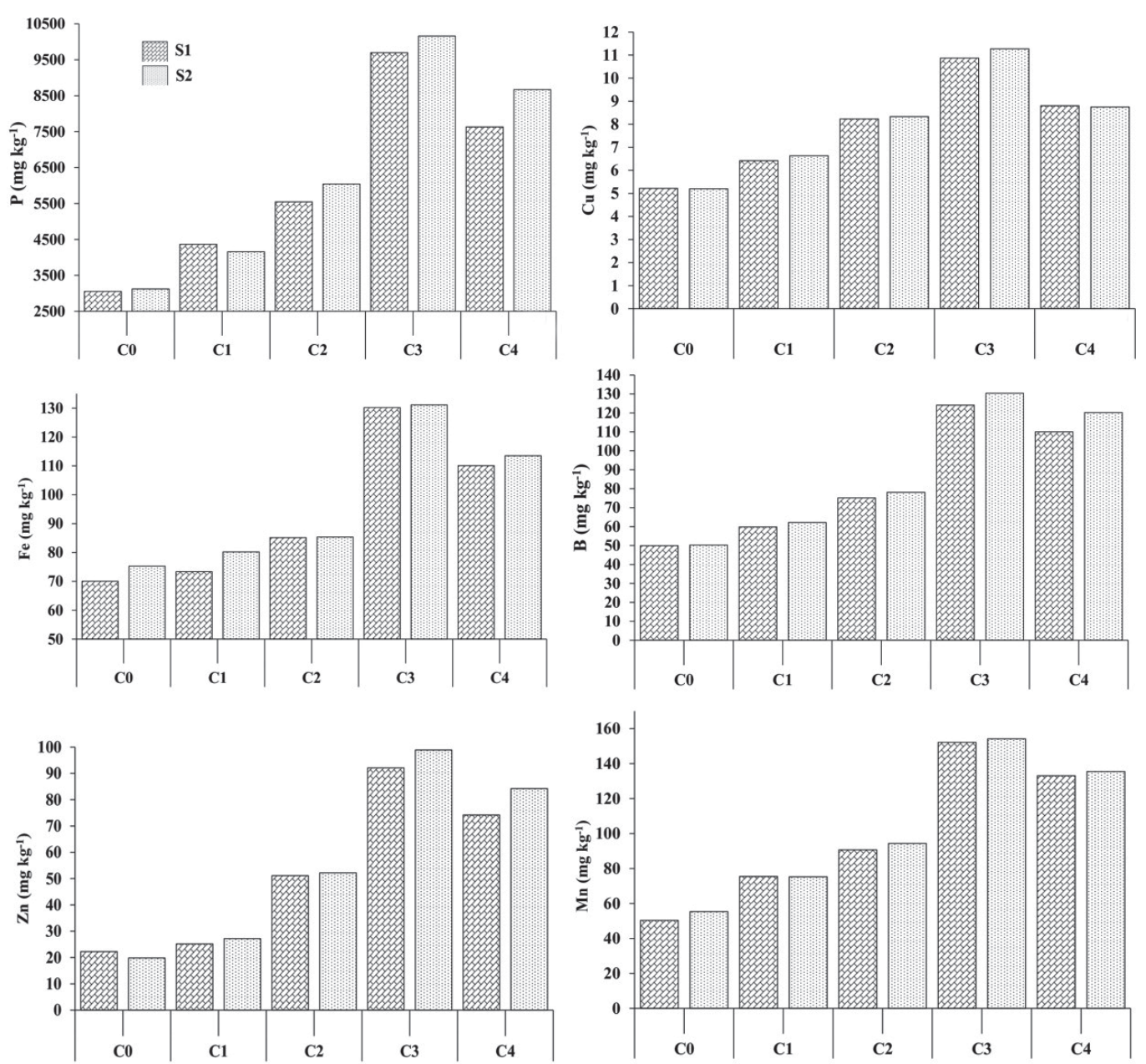

\begin{tabular}{c|c|c|c|c|c|c|c}
\hline \multicolumn{2}{c|}{ Elements } & P & Fe & Zn & Cu & B & Mn \\
\hline \multirow{4}{*}{$\begin{array}{c}\text { Tukey's HSD } \\
\text { Value }\end{array}$} & Soil Type & 95.70 & 5.08 & 5.08 & 1.8 & 0.42 & 4.34 \\
\cline { 2 - 8 } & Concentration & 367.03 & 10.23 & 10.23 & 3.62 & 0.84 & 8.75 \\
\cline { 2 - 8 } & Interaction & 519.06 & 14.47 & 14.47 & 5.11 & 1.19 & 12.37 \\
\hline
\end{tabular}

Fig. 5. Response phosphorus of micronutrients in plant tissues by different concentrations of sulfuric acid in two soils ( $\mathrm{S} 1=\mathrm{Silty}$ Clay Loam, S2 = Silty Clay, $\mathrm{C}=$ Concentration, Significant at $\mathrm{P} \leq 0.05)$. 


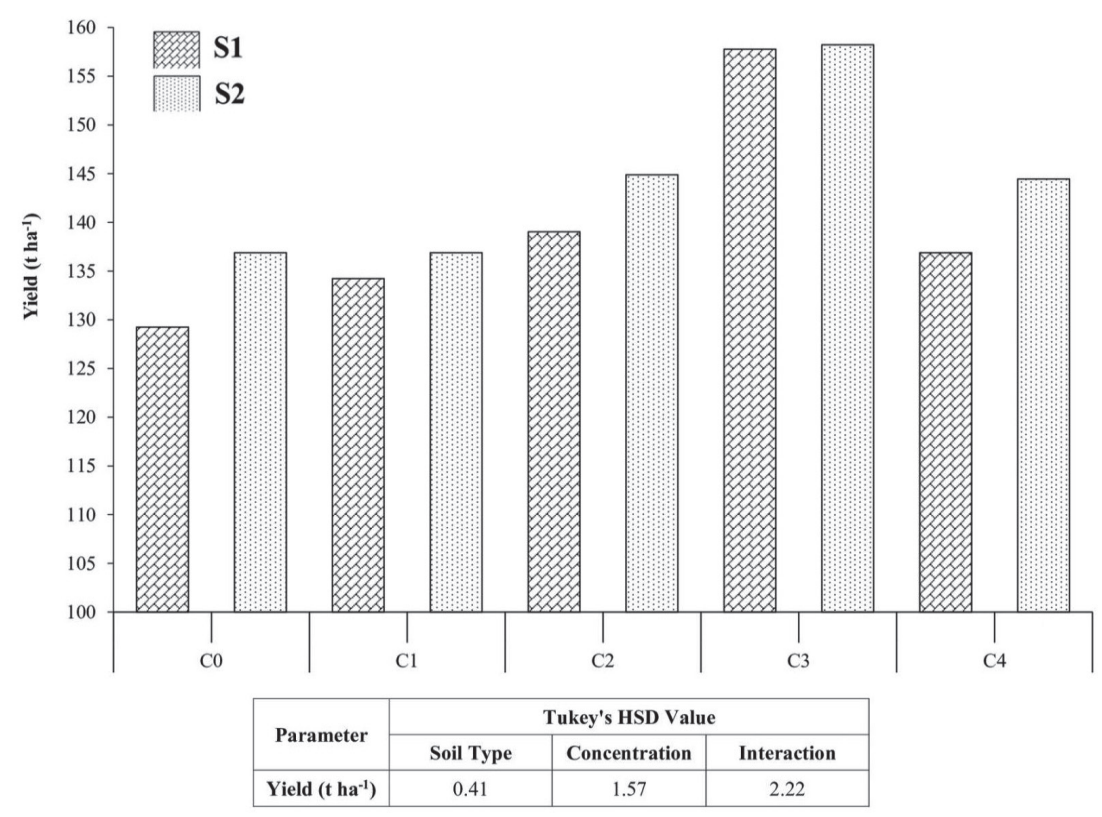

Fig. 6. Effect of different concentrations of sulfuric acid on cucumber yield in the two soils (S1 = Silty Clay Loam, S2 = Silty Clay, $\mathrm{C}=$ Concentration, Significant at $\mathrm{P} \leq 0.05$ ).

clay content in the soil, and the mechanism of the B adsorption step is considered to be ligand exchange with surface hydroxyl groups on the clay's particle edges. Therefore, additions of B could be made without it becoming toxic to plants because of a high adsorption capacity [26].

\section{Element Concentration in Plant Tissue and Cucumber Yield}

The best result for phosphorus, $\mathrm{Fe}, \mathrm{Zn}, \mathrm{Mn}, \mathrm{Cu}$ and $\mathrm{B}$ in the cucumber stem after harvesting was obtained by the fourth concentration $\left(3 \mathrm{ml} \mathrm{L}^{-1}\right)$, as this concentration showed statistically significant $(\mathrm{P} \leq 0.05)$ effects in increasing the number of elements in the plant stem tissues. The amount of $\mathrm{Cu}, \mathrm{Fe}, \mathrm{B}, \mathrm{Mn}$ and $\mathrm{Zn}$ in the leaves increased with a decrease in $\mathrm{pH}$ in treatments, particularly the fourth factor as well as $\mathrm{P}$ concentration (Fig. 5). In addition, the fourth concentration of sulfuric acid $(\mathrm{P} \leq 0.05)$ had a statistically significant impact on the yield (158.22 $\left.\mathrm{t} \mathrm{ha}^{-1}\right)$ of the cucumber plant (Fig. 6). The acidification of soil might cause an increase in the dissolution of minerals containing microelements. Also, the absorbance of $\mathrm{B}$ by plants in $\mathrm{H}_{3} \mathrm{BO}_{3}$ form, and an increase in soil $\mathrm{pH}$, can result in the dissociation of $\mathrm{H}_{3} \mathrm{BO}_{3}$ and transformation into $\mathrm{H}_{2} \mathrm{BO}_{3}$ form [27]; finally, the availability of boron to the plants would be decreased. As a result, the B uptake is decreased by increasing the $\mathrm{pH}$ of the soil solution. However, in this work, the concentration of micronutrients in cucumber leaves was similar to the study of Kreij et. al. [28]. Therefore, it seems that soil acidification to a $\mathrm{pH}$ range of about 5.5 improved the provision of micronutrients for cucumber plants. Fageria [29] also explained that a decrease in $\mathrm{pH}$ of irrigation water caused an increase in micronutrient uptake. On the other hand, Ghehsareh and Samadi [17] in their work on corn found that an increase of phosphorus uptake by the crop was obtained by acidifying irrigation water in the corn plantation.

As the availability of microelements and their uptake to the plant are improved by reducing the $\mathrm{pH}$ value, the yield is noticeably enhanced. The improvement of this parameter is probably due to an increase in the amount of chlorophyll in the leaves, which results from a decrease in alkalinity. Moreover, the highest amount of chlorophyll in leaves can be obtained from plant leaves in an acidic media, as the amount of chlorophyll in leaves can be an important index in determining the rate of photosynthesis [30]. Also, gains in high yields and good quality of cucumber depend on a convenient supply of macro- and microelements into the plant. Nutrient deficiency, particularly microelements, in plants can cause deterioration in plant resistance to detrimental environmental factors: declining yields and quality can occur [31]. However, the most important nutrients for cucurbits, especially cucumber, which are mainly affected by soil $\mathrm{pH}$ are $\mathrm{P}$ and micronutrients in the soil [32]. As a result, the $\mathrm{pH}$ for cucumber production is managed at 5.5-6.5, levels ordinarily used for plant production, and it has been observed that a target $\mathrm{pH}$ of 7.0 resulted in a $9.5 \%$ increase in the growth rate compared to the 5.0 treatment when the soil was acidified with an acid to manage the $\mathrm{pH}$ value [33].

\section{Conclusions}

Soil $\mathrm{pH}$ values noticeably were decreased by the addition of a low concentration of sulfuric acid. The values of soil $\mathrm{pH}$ were regularly decreased by increasing 
sulfuric acid $\left(\mathrm{ml} \mathrm{L}^{-1}\right)$. The lowest soil $\mathrm{pH}$ was obtained by $\mathrm{C} 4\left(5 \mathrm{ml} \mathrm{L}^{-1}\right)$. The availability of phosphorus and micronutrients ( $\mathrm{Fe}, \mathrm{Zn}, \mathrm{Cu}, \mathrm{B}$ and $\mathrm{Mn}$ ) was markedly improved by $\mathrm{C} 4\left(5 \mathrm{ml} \mathrm{L}^{-1}\right)$, and their concentration in plants were also improved particularly in (S2). As the acid reduces the soil $\mathrm{pH}$ temporarily, it would be useful for the elements to be adsorbed by the plant. Consequently, cucumber yield is enhanced, particularly in calcareous soils that have a higher soil $\mathrm{pH}$ that restricts the availability of most elements, especially phosphorus.

\section{Acknowledgements}

This research did not receive any specific funding.

\section{Conflict of Interest}

The author declares no conflicts of interest.

\section{References}

1. RENNER S.S., SCHAEFER H., KOCYAN A. Phylogenetics of Cucumis (Cucurbitaceae): cucumber ( $C$. sativus) belongs in an Asian/Australian clade far from melon (C. melo). BMC Evol. Biol., 7, 58, 2007.

2. MABOKO M.M., D.U. PLOOY C.P., CHILOANE S. Yield and mineral content of hydroponically grown minicucumber (Cucumis sativus L.) as affected by reduced nutrient concentration and foliar fertilizer application. HortScience, 52 (12), 1728, 2017.

3. HAVLIN J., HEINIGER R. Soil fertility management for better crop production. Agronomy, 10 (9), 1349, 2020.

4. ESMAIL A.O., SHEIKH-ABDULLAH S.M., MARUF M.T. Phosphorus availability in entisols, inceptisols, and mollisols of Iraqi Kurdistan. Soil Science, 184 (3), 95, 2019.

5. RAMÍREZ-PÉREZ L., MORALES-DÍAZ A., DE ALBA-ROMENUS K., GONZÁLEZ-MORALES S., BENAVIDES-MENDOZA A., JUÁREZ-MALDONADO A. Determination of micronutrient accumulation in greenhouse cucumber crop using a modeling approach. Agronomy, 7 (4), 2017.

6. RATE A.W., SHEIKH-ABDULLAH S.M. The geochemistry of calcareous forest soils in Sulaimani Governorate, Kurdistan Region, Iraq. Geoderma, 289, 54, 2017.

7. MAM-RASUL G. A. Zinc Sorption in Calcareous Soils of the Kurdistan Region of Iraq. Soil Science, 184, 60, 2019.

8. SHEIKH-ABDULLAH S.M. Availability of Fe, $\mathrm{Zn}, \mathrm{Cu}$, and $\mathrm{Mn}$ in soils of Sulaimani Governorate, Kurdistan Region, Iraq. Soil Science, 184 (3), 87, 2019.

9. KHORSANDI F. Sulfuric acid effects on iron and phosphorus availability in two calcareous soils. Journal of Plant Nutrition, 17 (9), 1611, 1994.

10. SOAUD A.A., AL DARWISH F.H., SALEH M.E., EL-TARABILY K.A., SOFIAN-AZIRUN M., RAHMAN M.M. Effects of elemental sulfur, phosphorus, micronutrients and Paracoccus versutus on nutrient availability of calcareous soils. Australian Journal of Crop Science, 5 (5), 554, 2011.

11. GROENENDYK D.G., FERRE T.P., THORP K.R., RICE A.K. Hydrologic-Process-Based soil texture classifications for improved visualization of landscape function. PLoS One, 10 (6), 2015.

12. LINDSAY W.L., NORVELL W.A. Development of DTPA micronutrient soil test for zinc, iron, manganese and copper. Soil Science Society of America Proceedings, 42 , 421, 1978.

13. ANDERSON D.L., HENDERSON L.J. Sealed chamber digestion for plant nutrient analysis. Agronomy Journal, 78, 937, 1986.

14. SINGH H., REDDY M.S. Effect of inoculation with phosphate solubilizing fungus on growth and nutrient uptake of wheat and maize plants fertilized with rock phosphate in alkaline soils. European Journal of Soil Biology, 47 (1), 30, 2011.

15. SUMNER M.E., YAMADA T. Farming with acidity. Communications in Soil Science and Plant Analysis, 33 (15-18), 2467, 2002.

16. MARUF M.T., MAM RASUL G.A. Effect of humic acid and sulfur fertilizer levels on some physiological traits of maize (Zea mays L.) on calcareous soil. Applied Ecology and Environmental Research, 17 (6), 13199, 2019.

17. GHEHSAREH A.M., SAMADI N. Effect of soil acidification on growth indices and microelements uptake by greenhouse cucumber. African Journal of Agricultural Research, 7 (11), 1659, 2012.

18. ALI F., SADIQ A., ALI I., AMIN M., AMIR M. Effect of applied phosphorus on the availability of micronutrients in alkaline-calcareous soil. Journal of Environment and Earth Science, 4 (15), 143, 2014.

19. BAJGIRAN A.R. Influence of Soil Amendments and Soil Properties on Macro - and Micronutrient Availability to Microorganisms and Plants. Swedish University of Agricultural Sciences, Crop Production Ecology, 2013.

20. SHUMAN L.M. Effect of liming on the distribution of manganese, copper, iron, and zinc among soil fractions. Soil Science Society of America Journal, 50, 1236, 1986.

21. SILVA RD. C. FD., SILVA F. B. VD., BIONDI C.M., NASCIMENTO C.W.AD., OLIVEIRA E.C.AD. Assessing the content of micronutrients in soils and sugarcane in different pedogeological contexts of northeastern Brazil. Revista Brasileira de Ciência do Solo, 43, 2019.

22. NAJAFI-GHIRI M., GHASEMI-FASAEI R. FARROKHNEJAD E. Factors affecting micronutrient availability in calcareous soils of southern Iran. Arid Land Research and Management, 27 (3), 203, 2013.

23. METWALLY A.I., MASHHADY A.S., FALATAH A.M., REDA M. Effect of $\mathrm{pH}$ on zinc adsorption and solubility in suspensions of different clays and soils. Zeitschrift für Pflanzenernährung und Bodenkunde, 156, 131, 1993.

24. CHUKWUMA M.C., ESHETT E.T., ONWEREMADU E.U., OKON M.A. Zinc availability in relation to selected soil properties in a crude oil polluted Eutric Tropofluvent. International Journal of Environmental Science and Technology, 7 (2), 261, 2010.

25. RENGEL Z. Availability of $\mathrm{Mn}, \mathrm{Zn}$ and $\mathrm{Fe}$ in the rhizosphere. Journal of Soil Science and Plant Nutrition, 15 (2), 397, 2015

26. STEINER F., LANA MD. C. Effect of $\mathrm{pH}$ on boron adsorption in some soils of Paraná, Brazil. Chilean journal of agricultural research, 73 (2), 28, 2013.

27. BARBER S.A. Soil Nutrient Bioavailability. 2 ed. New York, USA: John Wiley and Sons; 1995. 
28. KREIJ D.C., SONNEVELD C., WARMENHOVEN M.N., STRAVER N. Guide Values for Nutrient Element Contents of Vegetables and Flowers Under Glass. 3 ed. Naaldwijk, Aalsmeer, Netherlands 1992.

29. FAGERIA N.K. Role of soil organic matter in maintaining sustainability of cropping systems. Communications in Soil Science and Plant Analysis, 43 (16), 2063, 2012.

30. DUCHOVSKIS P., BRAZAITYTE A., JUKNYS R., JANUŠKAITIENE I., SLIESARAVIČIUS A., RAMAŠKEVIČIENE A., BURBULIS N., ŠIKŠNIANIENE $\quad$ J.B., BARANAUSKIS K., DUCHOVSKIENE L., STANYS V., BOBINAS C. Changes of physiological and genetic indices of Lycopersicon esculentum Mill. by cadmium under different acidicity and nutrition. Polish Journal of Environmental Studies, 15 (2), 235, 2006.

31. RUTKOWSKA B., SZULC W., SOSULSKI T., STĘPIEŃ W. Soil micronutrient availability to crops affected by long-term inorganic and organic fertilizer applications. Plant, Soil and Environment, 60 (5), 198, 2014.

32. MOUSAVI S.R., SHAHSAVARI M., REZAEI M. A General overview on manganese (Mn) importance for crops production. Australian Journal of Basic and Applied Sciences, 5 (9), 1799, 2011.

33. BLANCHARD C., WELLS DE., PICKENS JM., BLERSCH DM. Effect of $\mathrm{pH}$ on cucumber growth and nutrient availability in a decoupled aquaponic system with minimal solids removal. Horticulturae, 6 (1), 2020. 